\title{
Evolution of International Humanitarian Law and War: Crime in International Proportions
}

\author{
Renata Mantovani De Lima1, Michelle Batista ${ }^{2,3}$ \\ ${ }^{1}$ Pontifical Catholic University of Minas Gerais, Belo Horizonte, Brazil \\ ${ }^{2}$ University of Itaúna, Itaúna, Brazil \\ ${ }^{3}$ Law School, University of the State of Minas Gerais, Diamantina, Brazil \\ Email: michelleabatista@hotmail.com
}

How to cite this paper: De Lima, R.M. and Batista, M. (2017) Evolution of International Humanitarian Law and War: Crime in International Proportions. Open Access Library Journal, 4: e4107. https://doi.org/10.4236/oalib.1104107

Received: November 1, 2017

Accepted: December 16, 2017

Published: December 19, 2017

Copyright () 2017 by authors and Open Access Library Inc.

This work is licensed under the Creative Commons Attribution International License (CC BY 4.0).

http://creativecommons.org/licenses/by/4.0/

\begin{abstract}
The involvement of States in dispute over power, the ethnic, cultural and religious diversity of the human element that composes these States, the terrorist threat, as well as economic and technological development, underpin and imply an increase in the destructive power of armed conflicts, a cruel and sad reality of the history of humanity. Wounds, mutilations, displacements and suffering of people, destruction of the environment and goods shock the world. Thus, at first, this study presents the historical bases that determined the creation of humanitarian law. After, it makes considerations about its framework and some scores on the sad consequences of the war. Humanitarian law must be considered fundamental to any legal system, even overlapping with the internal norms of States, which shows the recognition of the link between the internal plan and the international reality. It is necessary to understand that a society free from impunity, based on a culture of responsibility and committed to the construction of truth and justice, establishes solid pillars in the search for fulfillment and respect for humanitarian law and human rights.
\end{abstract}

\section{Subject Areas \\ International Relations, Law}

\section{Keywords}

War Crimes, Humanitarian Law, Armed Conflict, Human Rights

\section{Introduction}

The involvement of States in dispute over power, the ethnic, cultural and reli- 
gious diversity of the human element that composes these States, the terrorist threat, as well as economic and technological development, underpin and imply an increase in the destructive power of armed conflicts, a cruel and sad reality of the history of humanity. Allied to this fact, the proportion of victims involved in conflicts, whether combatants, ex-combatants, or the civilian population, reached alarming levels in the late twentieth century. Armed conflicts of the twentieth century caused about 90 million fatalities [1]. It is true, however, that the nature of conflicts has been changing since the end of the Cold War, with a progressive decrease in fatalities. If the two Great Wars victimized about 70 million people, the current conflicts are increasing and numerous, amount to around 3 million [2]. However, in the balance, injuries, mutilations, displacements and suffering of people, destruction of the environment and of goods shock the whole world.

Currently, inter-State conflicts have given way to intra-State conflicts. "In 2010, a total of 363 conflicts were observed. Among these were six wars and 22 severe crises, amount to 28 highly-violent conflicts, i.e. conflicts fought out with the use of massive violence" [1]. Consequently, it can be seen that if, apparently or even theoretically, cooperation among States, respect for human rights norms and negotiation mechanisms are proving to be "more efficient", and consequently avoiding or reducing the outbreak of wars, on the internal plane of many States the same does not occur. In fact, it is here that the greatest violations of human rights and humanitarian law have taken place in recent times. Conflicts that previously had global progression and grounding in an ideological dispute are beginning to stand out because of their cultural and political nature, which in turn causes the disintegration of a set of values capable of substantiating the legitimacy of the State or of the existing [3].

In such conflicts, transgression and disrespect for minority rights are evident, the losses are immeasurable, and international peace and security are threatened. Although war is considered an international crime, its prevention and punishment must always be sought in international cooperation. In order to address these issues and in order to compose these relationships, measures of different species are adopted by international society and international bodies. Just as an example are declarations of repudiation by States, humanitarian interventions and the establishment of Courts by the United Nations. It is certain, however, that this is not enough, since we must take care of the evils caused by war, safeguarding humanity from its consequences and catastrophes. And that is the main objective of humanitarian law: coined on the principles of universally recognized humanity and dignity, protecting people from the scourges and hostilities of war.

International society seeks, more and more, to strengthen it, especially through International Organizations, whether regional or global. In this regard, they take care of it, in many ways, for the maintenance and promotion of peace, human rights and development. To that end, they adhere to the guiding principles of international law, namely peacekeeping, peaceful resolution of disputes, 
prohibition of the use of force, self-determination of peoples, isonomy and sovereignty of States, and good faith. Therefore, in the first place, the historical bases that determine the creation of humanitarian law will be presented. Subsequently, considerations its framework will be made, as well as some scores on the sad consequences of war.

\section{The Development of International Humanitarian Law}

The construction of an international normative system focused on the development of international humanitarian law can be verified throughout several moments in the history of humanity. This is because, intrinsically linked to social facts, the law is conditioned by the behavior of society, which, in turn, is also conditioned by legal norms. From this point of view, it is necessary to clarify that conditioning implies in influencing, interfering, generating the expectation that Law and society will act according to a determined way. Social norms when institutionalized impose certain patterns of behavior that aim to govern and regulate social life. That is why it ends up interfering in the conduct of people in the social environment. In this way it is certain that society interacts with the law and is influenced by it. Thus, by establishing juridical norms, they shape society; however, this also dictates patterns that comes out of informality, and becomes positive law. It is clear that in order to regulate internal relations and international relations, the need for specific legal rules is required.

Concerning the international sphere, it is has to be mentioned that with the increasing expansion and intensity of relations between State actors, and the delicate complexity of these relations, conflicts between nations around the world become potential. The need for institutionalization and the imposition of rules, based on the law of nations, surpasses the limitation of domestic legal systems in equating conduct that goes beyond national borders, as well as guiding the punishment of transgressions which effects are projected throughout international society.

The law of the people places the individual at the center of the system of international relations. Antônio Augusto Cançado Trindade writes about the subject: "ultimately, all the rights exist for the human being, and the law of the people does not make exception to this, guaranteeing to the individual his rights and the respect of his personality". This same author also provides reflections of important theologians on the law of nations. According to Francisco Suárez, "the law of the people reveals the unity and universality of the human race; States need a legal system that regulates their relations as members of the universal society." In Francisco de Vitória's appreciation, "the law of nations regulates an international community made up of human beings organized socially in States and coextensive with humanity itself; the reparation of violations of (human) rights reflects an international need fulfilled by the law of the people, with the same principles of justice applying to both the States and the individuals or peoples that form it." In the conception of Hugo Grotius's jus gentium, "the 
State is not an end in itself, but a means to ensure social order according to human intelligence" [4].

International humanitarian law means a whole legal framework, established through treaties or custom, in order to resolve issues arising in international or non-international armed conflicts. Such standards safeguard people and property exposed or likely to be affected by conflict. Thus, the rights of the conflicting are limited, both in the methods, resources and resources employed.

Thus, in order to understand international humanitarian law, it is necessary to look for antecedents related to the outbreak of wars, since the emergence of norms that safeguard individuals at the international level stems from wars, armed conflicts and confrontations in general. Having said that, it is necessary, although synthetically, to demarcate its influences.

\subsection{Historical Background}

The task of clearly delineating the initial framework of international humanitarian law is difficult and conducive to multiple doctrinal positions. On this, says Sandra Szurek: "it is certainly not possible to date precisely the appearance of a new branch of law as it is possible to locate the source of a river and as doctrinal divergences has essentially in the matter the elements that can be considered determinants" [5]. However, it is irrefutable that certain antecedents denote the emergence and development of a normative movement common to the international society. On the other hand, contemporary events have contributed to a convergence in the establishment and improvement of repressive and preventive mechanisms related to armed conflicts. As a result, it was possible to envisage a remarkable evolution of the International Humanitarian System, which tends to combat the impunity of the great perpetrators of crimes within an international society strongly characterized by its decentralization and heterogeneity. Pellet also addresses international society as a "minor subject of international law". He explains: "in the current State of international law, the international community cannot pass from a minor subject of law. Minor subject, first by the breadth of his ability to enjoy. Minor subjects, especially because it is necessary to take the form of an international organization, and because there is a risk that the international community will be able to recover its competences from the member States of this organization" [6]. Antonio RemiroBrotóns, on the other hand, characterizes contemporary international society as universal, heterogeneous and polymorphic [7].

The Law of Armed Conflict is as old as the practice of war that accompanies man from the earliest days to the present day. The history itself, to a great extent, is studied from the standpoint of political battles and disputes. In its origins, the war was characterized by the absence of any rule beyond the law of the stronger. In antiquity the first sketches of humanitarian law emerge, as in the Hamurabi Code, which in its epilogue States: "I decree these laws in order to prevent the strong oppress the weak." Other ancient civilizations such as China, India, Per- 
sia, Greece and Muslims also argued favorably for the necessity of humanity or ethics in the wars.

In the Middle Ages, Christianity progressed with a spiritual reform movement, seeking to contain the many abuses practiced, based on the law of the strongest, and transforming churches and monasteries into places of asylum where violence could not enter, as well as moderating activities military. The first humanitarian institutions are thus created: the Peace of God and the Truce of God. The first, defined in $989 \mathrm{AD}$ at the Council of Charroux, proclaimed the inviolability of churches, monasteries, the poor, clergy, merchants, pilgrims, farmers and their goods. The second, instituted by the Council of Elne in 1027, prohibited the fighting during certain periods of the liturgical calendar, with excommunication being foreseen as a sanction for cases of violation of these principles [8].

It is true, however, that the humanitarian ends of these institutions were not exclusive. The idea of a just war also developed in medieval times, although its concept was coined by St. Augustine (354-430). Fighting, in this case, could be tolerated when it was a just or defensive cause. In this case, protection was reserved only for the victims of the State conducting such a war. But, besides Augustine, other thinkers took up this tradition: Thomas Aquinas (1225-1274); Francisco de Vitória (1483-1546); Francisco Suárez (1548-1617); Vattel (1714-1767); Hugo Grotius (1583-1645), in his classic book Jure Belli ac Pacis ("On the rights of war and peace"), from 1625; Samuel Pufendorf (1632-1694) and Christian Wolff (1679-1754).

Grotius, however, is probably the one most devoted to the elaboration of the concept and doctrine. However, it is only with the Enlightenment and its humanist doctrine that the military is limited to belligerence, sparing the civilian population from catastrophes caused by war. Rousseau (The Social Contract, 1762) and Emeric de Vattel (Right of the Peoples, 1758) were its chief authors, both having buried the just war thesis and its justification arising from the sovereign reason of the States.

\subsection{Origin and Evolution of International Humanitarian Law}

As part of the doctrine, to maintain that international humanitarian law is a new branch of law is rather excessive, hence the development of rules, which in turn reveal such discipline, can be seen for a long time through different chapters of history. As a traditional branch of International Law its original landmark can be remembered by the emblematic Battle of Solferino, more precisely on June 24, 1859.

On that occasion, in the Italian commune of the Lombardy region called Solferino, a battle was fought between the French and Sardinian troops commanded by Emperor Napoleon III against Austrian soldiers who killed approximately 40,000 people after 15 hours of carnage and shedding of blood. Of these, about $60 \%$ died from injuries that could not be treated. The medical services of the 
French and Sardinian armies were overwhelmed. At the time the average was of 1 doctor for every 500 injured.

Jean-Henry Dunant, a Swiss merchant who happened to be in the area on business, witnessed the bloody battle and horrified by the suffering of soldiers, gathered local volunteers to provide humanitarian aid to the victims of the war. The group cared for all men equally, regardless of which side they had fought, inspiring women to come up with the phrase "tuttifratelli" (all brothers).

In the face of what he had witnessed, he returned home disturbed and in 1862 he wrote the book "Memories of Solferino", in which he formulated a double wish: that in time of peace, in each country a voluntary society of aid was constituted; and that States ratify an international principle to ensure protection and assistance to victims of armed conflict and conflict.

In 1863 the Red Cross was established by a Committee composed of five persons (Dunant, the physicians Appia, Maunoir and Moyner and General Dufour) and asked the Swiss authorities to convene a Diplomatic Conference, which was responsible for signing, by representatives of 12 States, of the Geneva Convention of 1864 which took care of improving the situation of wounded and sick soldiers during battles.

Since the signing of the Geneva Convention of 1864, under the auspices of the International Committee of the Red Cross, which are responsible for revising the treaties on international humanitarian law, important agreements have emerged with the following chronological highlights:

- St Petersburg Declaration of 1868 (regulating the use of explosive or flammable projectiles);

- Conventions signed at the first Hague Peace Conference of 1899 (dealing with the laws and customs of war on land and the adaptation to maritime warfare of the principles of the Geneva Convention of 1864);

- Review and improvement in 1906 of the Geneva Convention of 1824;

- Conventions signed at the Second Peace Conference in The Hague in 1907 (which represent the principal documents on land and sea war);

- Protocol of Geneva of 1925 (deals with the prohibition of the use of asphyxiating, toxic or similar gases and of bacteriological methods in war);

- Kellog-Briand Pact, signed in 1928 (which put war "outlawed");

- Geneva Conventions of 1929 (two Geneva Conventions of 1929, the first revising and improving the Geneva Convention of 1906 and the second Convention on the Treatment of Prisoners of War);

- 1949 Geneva Conventions (total of four Conventions);

- The Hague Convention of 1954 (for the protection of cultural property in case of armed conflict);

- Convention on the Prohibition of the Development, Production and Stockpiling of Bacteriological and Toxic Weapons on Their Destruction, signed in 1972

- Additional Protocols of 1977 to the Geneva Conventions of 1949 (the first 
deals with the protection of victims of international armed conflicts and the second with respect to non-international armed conflicts);

- Convention on Prohibitions and Restrictions on the Use of Certain Conventional Weapons (there are three Protocols related to this Convention), signed in 1980;

- 1993 Convention on the Prohibition of the Development, Production, Stockpiling and Use of Chemical Weapons and on Their Destruction;

- Protocol on laser weapons that cause blindness, signed in 1995;

- Amendment in 1996 to the Second Protocol to the 1980 Convention, which deals with prohibitions and restrictions on the use of mines and other artifacts;

- Convention on the Prohibition of the Use, Stockpiling, Production and Transfer of Personal Mines and on their Destruction, signed in 1997.

Although the instruments of ius in bello are innumerable, two sets of humanitarian laws currently stand out because of their importance in international armed conflict law, namely the Geneva Conventions of 1949 and their Additional Protocols of 1977.

It is on these documents that the fundamental basis of the International Law of Armed Conflicts is based, the main purpose of which is to State the rules applicable during armed conflicts, whether international or national, in a way that restricts the rights of combatants by limiting of hostilities, and to protect the rights of noncombatants-both civilians and the military out of combat-stating the protection mechanisms of the people who have fallen into the hands of the enemy.

\section{The Catastrophes of War}

Armed conflicts, regardless of territorial size and destructive capacity, leave deep marks and grave consequences. Barbarism is continuous over time and takes on absurd proportions, not only in the quantity of deaths, damages of all orders, but of its technological innovations, destructive power and unimaginable means when we consider, mainly, the terrorist actions.

It is true that with the outbreak of warfare throughout the history of mankind the arms race has provided a considerable development of military armaments such as tanks, airplanes, radars, bombs, nuclear power, advanced, more and more highly technological and scientific. The costs of armed conflict in human lives are constantly increasing [9].

In addition to the current violations of the international normative body built over the last few years, human losses and material damage that are often difficult to measure should be considered as damaging effects of armed conflict. In addition to immediate sequelae, such aggression would cause long-term damage to the environment. Serious public health consequences have been caused because of contamination of water, soil, and the food chain with depleted uranium and other toxic substances. 
In the conflicts of the late twentieth century and the beginning of the twenty-first century, the destruction of several oil wells led to negative consequences, both ecologically and economically. In 1991, for example, Iraqi forces destroyed seven hundred oil wells in Kuwait, and in 1998 there were still 10 million cubic meters of soil contaminating. Two-fifths of Kuwait's drinking water aquifers remain contaminated. Ten million barrels of oil affected more than $1500 \mathrm{~km}$ of the Gulf coast. For 9 months the oil wells were on fire and the temperature in the area dropped by an average of 10 degrees Celsius. It is estimated that a thousand people died as a result of air pollution. By reaching industrial and military sites such as armament factories or refineries, acute chemical pollution on the site is generated. So the damage to the atmosphere was immeasurable.

Hunger, unemployment, loss of assets and the displacement of people are catastrophic results that end up destroying lives. Due to the complete lack of structure in the places of confrontation, an astonishing rate of unemployment must be considered, which implies a financial crisis also driven by exorbitant military expenditures.

This is compounded by discrimination, greater difficulties in accessing health services, diseases, family breakdown, physical and sexual abuse and labor exploitation, with consequences on mental health.

There are multiple consequences of armed conflicts on health, including institutions, people and resources dedicated to providing health services, such as training of professional and technical personnel, health research and the formulation and implementation of health policies.

Unfortunately, escalating conflicts involving chemical or nuclear attacks will significantly increase conflict mortality. Conflicts affect not only the locations of warlike confrontations, but the whole globe that ends up to a greater or lesser extent suffering with damage to the environment, financial reflexes and with long-lasting and large-scale displacements. These displacements negatively affect the international society as a whole, since the loss of productivity and capital weakens the economy. The exit of professionally qualified people from the country reduces the provision of basic services. Overburdened infrastructure in urban settings and increasing labor market pressure can result in deprivations for the resident population. Likewise, negative reactions from international society, especially from Islamic countries, anticipate growing international tension, an increase in the arms race and an expansion of recruitment and terrorist group actions.

\section{Conclusions}

An analysis of the framework of international humanitarian law and its process of development and consolidation shows that there are lessons to be learned and that the challenges faced in the past can bring the guidelines and hope for overcoming current challenges. The consequences of wars on life, quality of life, health, health care, prevention of diseases in war territory, among many other 
aspects are diverse, serious and complex. To pretend to describe them would be an extremely arduous and delicate task. At the same time, it is observed that several phenomena can also be expression and consequence of the conflict and, therefore, affect several victims and alter both their quality of life and the different physical, affective and psychosocial dimensions of health.

According to Michel Deyra [10], international humanitarian law or international law of armed conflicts aims to "humanize war by disciplining human beings in their acts of armed violence and giving protection to those who are in danger."

However, it is possible to observe the growing movement of reconstruction and effective protection of fundamental rights, placed as paradigms of the contemporary international order. The repression of armed conflicts, the defense of religious, ethnic and political plurality, or even the fight against impunity, must be constantly pursued, notwithstanding the fact that this is a long and arduous task.

The growing awareness that certain crimes committed within a national territory have repercussions at international level, in addition to violating basic and unavailable individual rights, brings with it the need to develop a system of preservation of peace. In this way, intra-State conflicts that did not fall within the competence of the Security Council are assumed to be transnational in nature, becoming the subject of the resolutions issued at the heart of Chapter VII of the UN Charter.

Humanitarian law, in turn, is considered fundamental to any legal system, even overlapping with the internal rules of the States, which shows the recognition of the link between the internal plan and the international reality. It is necessary to understand that a society free from impunity, based on a culture of responsibility and committed to the construction of truth and justice, establishes solid pillars in the search for fulfillment and respect for humanitarian law and human rights.

\section{References}

[1] Heidelberg Institute for International Conflict Research (2016) Conflict Barometer. https://www.hiik.de/en/

[2] Marshall, M.G. (2003) Major Episodes of Political Violence 1946-2002. Centre for Systemic Peace.

[3] Comité Internacional de La Cruz Roja (1998) Los Conflictos Armados Relacionados con la Desintegración de las Estructuras del Estado. Documento Preparatorio del Comité Internacional de la Cruz Roja Para la Primera Reunión Periódica Sobre el Derecho Internacional Humanitario.

[4] Trindade, A.A.C. (2004) Direitos Humanos: Personalidade e Capacidade Jurídica Internacional do Indivíduo. O Brasil e os Novos Desafios do Direito Internacional. Rio de Janeiro: Forense, 199-264.

[5] Szurek, S. (2000) Historique. La formation du Droit International Pénal. Droit International Pénal, 6.

[6] Daillier, P., Dinh, N.Q. and Pellet, A. (2003) Direito Internacional Público. 
Fundação Calouste Gulbenkian, Lisbon.

[7] Brotóns, A.R. (1987) Derecho Internacional Público. Tecnos.

[8] Grimberg, C. (1989) História Universal: O Fim da Idade Média. Publicações Europa América, Lisbon.

[9] United Nations Development Program (2016) UNDP-UN Human Development Report.

http://hdr.undp.org/sites/default/files/2016_human_development_report.pdf

[10] Deyra, M. (2009) Direito Internacional Humanitário. Gabinete de Documentação e Direito Comparado, Procuradoria Geral da República. 